\title{
Indonesia's Maritime Vision and the Prospect of Cooperation in the South China Sea
}

\author{
Masyithoh Annisa Ramadhani \\ Birmingham University, Birmingham B15 2TT, United Kingdom \\ ramadhannisa91@gmail.com
}

Submitted: 3 December 2015, Accepted: 17 March 2016

\begin{abstract}
Abstrak
Laut Tiongkok Selatan telah menjadi saksi terjadinya proyeksi kekuatan global dikarenakan besarnya peluang sumber daya alam yang tersimpan di dalamnya. Setidaknya terdapat enam negara yang menjadi negara penuntut (claimant states) dalam konflik Laut Tiongkok Selatan yaitu Republik Rakyat Tiongkok, Taiwan, Vietnam, Malaysia, Brunei, dan Filipina. Amerika Serikat sebagai aktor eksternal, tetap berupaya untuk meyakinkan bahwa kehadirannya tetap dibutuhkan untuk menjaga stabilitas kawasan. Situasi ini menimbulkan dilema keamanan (security dilemma) yang berakibat pada kompetisi kekuatan, sehingga menjaga perdamaian dan keamanan menjadi hal yang penting. Oleh karena itu, Indonesia sebagai salah satu negara yang berpengaruh di kawasan dan bukan merupakan negara pentuntut (non-claimant states) berupaya untuk menekankan pentingnya kerjasama regional untuk menjaga keamanan melalui visi maritim. Penelitian ini bermaksud untuk melihat sejauh mana kerjasama regional dapat menjadi sarana untuk (1) menstabilkan keamanan regional dengan mempertimbangkan pola ketergantungan antara negara, (2) mendorong terwujudnya kebersatuan ditingkat regional, dan (3) mengurangi kemungkinan proyeksi kekuatan global.

Keywords: Laut Tiongkok Selatan, security dilemma, Indonesia, visi maritime
\end{abstract}

\begin{abstract}
The South China Sea has witnessed an array of global power projections given the huge amount of potential resources there. There are at least six countries who committed to be claimant states; China, Taiwan, Vietnam, Malaysia, Brunei, and the Philippines. Despite its role as the external actor, the United States claimed that their presence is needed in order to preserve stability in the region. This vexing situation has led to security dilemma which brings about power competition thereby maintaining peace and security would be critical. Therefore, Indonesia as one of region's rising powers who commits to be a non-claimant state, iterated the importance of establishing cooperation to preserve regional security under maritime vision albeit its national interests at stake there. This research examined the extent to which Indonesia maintains neutrality while pursuing national interests in the South China Sea under the maritime vision. Cooperation could therefore become the tools for (1) stabilising regional security given the increase of interdependence among states, (2) forging the immersion of regional unity, and (3) lessening the global power projections.
\end{abstract}

Keywords: The South China Sea, security dilemma, Indonesia, maritime vision, national interests

\section{INTRODUCTION}

Unpredictable world situations where friends and foes might be twisted have led states to formulate a policy which aims to keep their national interests secure in international affair. The Asia Pacific has witnessed an array of cooperation and potential conflict due to power shifting in the region. The two dominant states in the region, the United States (U.S.) and China, are seemingly eager to balance each other given various forms of either bilateral or multilateral forum. Vexing situation of dealing with the longstanding conflict in regard to disputed territory seems to be conceivable in one of the richest marine biodiversity areas, notably known as the South China Sea. Given its importance as the most used sea passages in the world, many states are aware of taking advantage of it. However, the recent massive land- 
reclamation activity by China on the Spratly Islands in the South China Sea has alarmed many countries engaged in the Asia Pacific region. China insisted that maritime reclamation has been part of its legal activity on the sea. However, when other countries like Japan have been fortifying the Okinotiri Islands and demanded an exclusive economic zone, the United States has been silent on this matter (Huaxia, 2015).

United Nations Conventions on the Law of the Sea (UNCLOS) is thus expected to become a legal guideline for all claimants to comply with the peaceful dispute settlement. It is stated that every state has the right to establish the breadth of its territorial sea up to a limit of 12 nautical miles, measured from baselines determined in accordance with this convention (UNCLOS, 1982). However, China has made new claim over the "nine-dashed line" which embraces some $80 \%$ of the South China Sea is described as China's historic waters. This claim has raised the awareness of its neighbors such as the Philippines and Vietnam as they believe that they too are entitled to benefit from the natural resources and other potentials of the region. Sovereignty claims and energy vulnerability become the two major factors which exacerbate the dispute. As a sea which holds a huge amount of potential energy resources, it becomes potentially one of the most protracted conflict zones in Asia Pacific, where both regional and international players try to assert their unequivocal primacy over the disputed area. There are at least six countries with interests at stake in the competing territorial and jurisdictional claims of the South China Sea; China, Taiwan, Vietnam, Malaysia, Brunei, and the Philippines. Among all claimants, China persistently displays the most aggressive behaviour proven by the military build-up and public statement by Chinese officials in regard to their reluctance to engage with external parties in the dispute such as the U.S. On the other hand, the U.S. argued that they have underwritten regional security for decades, patrolling Asia's sea lanes and preserving stability, therefore their presence in playing a more contributing role in the region is needed (Clinton, 2015). Notwithstanding the fact that the U.S. has never been truly absent from Southeast Asia, the ongoing commitment to its regional allies, and overwhelming maritime military presence - the perception that the U.S. role in regional affairs has been declining since China's has been ascending cannot be easily dismissed (Anwar, 2013). I believe that the risks of further alleviated tensions could potentially increase. Therefore, unilateral action similar to China's in the Spratly Island would surely bring more harm than good in the dispute settlement effort.

At the height of global power projections, the Republic of Indonesia as one of ASEAN's founding fathers who has been actively promoting the principle of non-alignment notably known as its "non-block" approach in international affairs, has tried to become a pioneer in mitigating the potential risks surrounding the region such as initiating the discussions on the formulation of the Declaration of Conduct (DOC) whereby China is willing to join the conduct despite its current assertiveness. However, as a sovereign state, Indonesia must also have its national interests at stake, despite its commitment to contribute to peace and security formation in both regional and international affairs. Natuna Island claimed by China, is in fact part of Indonesian territory. As of July 2015, the Indonesian Navy has agreed to build their military bases in the forefront of Natuna Island. In October 2014, Indonesia's newly elected President Joko Widodo announced a new top priority in terms of foreign policy concern, emphasizing the importance of maritime vision through the officially announced vision of "Global Maritime Nexus" (GMN). Through this vision, Indonesia is expected to play a more contributive role in the formation of regional security and economic integration. Moreover, GMN also aims to enhance more cooperation on the basis of regionalism, in order to enhance mutual benefits for instance in terms of international trade. It therefore remains a dilemma as to how Indonesia might pursue national interests while maintaining its neutral position as a non-claimant state despite the interest at stake in one of the resource-rich islands of the South China Sea 
called Natuna Island. However, Indonesia is intent on relying on the status quo, where non claimant status is becoming their foundation in dealing with the South China Sea dispute.

A variety of factors, therefore, have contributed to the subject matter and research question here; the increasing level of China's assertiveness in the disputed area, the U.S. commitment to strengthening benign intention with its partners in Southeast Asia, some of them being claimant states, and Indonesia's ambition to establish maritime-based cooperation in order to pursue their own benefits and further bolster an integrated regional architecture in order to advance politics, economic, as well as security interests for all. Even though it is not a panacea, cooperation could be used as a tool to refrain from the use of force in any dispute settlement. States bound into such a cooperative partnership form will be less likely to take an assertive attitude towards their partners. If they do an adversarial attitude, this would potentially bring about a complex security dynamic that further threatens the existing cooperation. Maritime vision invigorated by Indonesia could potentially bring about a more inclusive region, since cooperation based on shared opportunities is promoted. Therefore, question to explore would be:

To what extent does Indonesia through its maritime vision maintain neutrality in the South China Sea dispute while pursuing national interests at stake?

I will look at the extent to which Indonesia through its maritime vision, could maintain neutrality within the breadth of uncertain geopolitics in the Asia Pacific, while at the same time pursuing its national interests at stake in the South China Sea. The data analysis will focus on the following details; first, it will explain the global power projections in the South China Sea which involve the U.S. and China. Second, it will explain the significance of maritime vision invigorated by Indonesia towards the maritime boundary dispute in the South China Sea. My argument that will be elaborated later makes three significant points. First, Indonesia will strive to maintain good relations with all claimant and non-claimant states involved in the South China Sea dispute in order to pursue its national interests at stake. Second, maritime vision could become a lynchpin to enhance unity among regional actors such as ASEAN members, in order to enhance benefits to them. Third, this could further reduce the height of the great power projection in the South China Sea, due to an array of potential shared opportunity through cooperation.

\section{THEORETICAL FRAMEWORK} SECURITY DILEMMA

Research and attempts pursued by both academicians and think-tanks have been helpful in examining states' behaviour through the basis of security dilemma. Started from the basic assumption of world politics according to neorealist which believed that an anarchic international system is a source of conflict, thus state faced a condition as they need to make sure that they are safe from other state's hostile intention. In order to strive a security attainment from any plausible attack, both groups and individuals living such a constellation are therefore driven to acquire more and more power in order to escape the impact of the power of others (Herz, 1950). Therefore states will focus on the quest for security in the midst of anarchic systems. He further suggested that groups and individuals living in such a constellation must be, and usually are, concerned about their security from being attacked, subjected, dominated, or annihilated by other groups and individuals. Thus, maximizing efforts to prepare for the worst circumstance led by insecurity is rising as no state can be certain about their security at stakes. I would argue that this action is justifiable as long as it does not threat other neighbours. World politics is an unpredictable constellation where friends and adversaries may be twisted. It may render to the power competition if it goes unmanaged. Power competition is partly emerged because no state wants to leave behind by others. Charles Glaser defined security dilemma as 'situation in which the military forces required by a state to protect itself threaten the forces other states need to protect themselves; in that 
situation states seeking security cannot avoid threatening each other's military capability' (Glaser, 1992). Security dilemma partly emerged as the situation by which a state tries to increase its security decrease the security of others. This is actually not a new phenomenon in world politics. Take a look on the example when Germany started building a powerful navy before World War I, Britain who at that time also needed a large navy to maintain the shipping lanes open, objected that this action could only be an offensive weapon aimed at them (Jervis, 1978). It is somehow important for states to be able to define other's actions as misperceiving of other's "defensive" actions could be regarded as "aggressive" as what happened during Cold War between the United States and the Soviet Union (Snyder, 1984).

Therefore, Jervis' findings that an increase in one state's security decreases the security of others, notably known as the central point of security dilemma (Jervis, 1978) might be taken into account in understanding the basic idea of analyzing state behavior on security matters. Nonetheless, I believe that one state's security increase is not only decreasing others' security, but also themselves in the first beginning. Once state ' $\mathrm{A}$ ' increases their security preponderances by the means to make them safe from other's attack, it will trigger other states, name it state ' $\mathrm{B}$ ' to, therefore feel insecure due to its vulnerability thereby implying them to increase security as well. It will in return increase state vulnerability and automatically decrease its security. International system which consists of the states and organization established imply to the existing anarchic system, for it lacks an overarching supranational government, but is not chaotic thereby system is defined by its key actors, their interactions, hierarchies of power, and influence among them (Clemens, 1998). As the consequence of an uncertain strategic situation, security dilemma is formed as a type of insecurity dynamic between states, thereby state's knowledge of the other state's motives is important in order to engage in the worst-case scenario planning (Glaser, 1997).

Glaser further argued that every state facing security dilemma is more likely trapped in these patterns: first, cooperate with others by the consequence other may take advantage of them but they may get benefit due to the shared opportunities, or second, no cooperation but maximizing own effort to pursuit their interests by achieving more benefits but less secure as suspicion about others' intention will be more likely. This is formed as the dilemma between costs of war and gains from cooperation bid. According to Deutsch cited in Jervis (1978), there are four elaborations in analyzing security dilemma and its relations with cooperation. First, statesmen understand that entering war means being ready to set off a chain of unpredictable and uncontrollable events; second, domestic costs of wars such as memories of disruptions must be weighed since even the strong states can be undermined by dissatisfaction with the way the war is run and by necessary mobilization of people and also ideas; third, turning to the advantages of cooperation, for states with large and diverse economies the gains from economic exchange are rarely if ever sufficient to prevent war. And fourth, the gains from cooperation can be increased, not only if each side gets more of the traditional values such as wealth but also other's well-being positively. However, through discussions, meetings, and formal arrangements of cooperation, the high probability of conflict might be reduced gradually as trust deficit declines respectively.

The South China Sea has witnessed a great power competition due to security dilemma faced by international actors surrounding. The United States and China as region's two big actors are seemingly willing to assert their influence in the regions given abundant national interests that they hold. The U.S. deep engagement in the region is seen by China as threat to their interests in the region. China is reluctant to maintain the status quo in where the U.S. has a huge portion in regional constellation by being a revisionist instead. A.F.K Organski and Jacek Kugler defined status quo states as those that have participated in designing the "rules of the game" and stand to benefit from these rules, while "challengers" or revisionist states want a "new place for themselves in interna- 
tional society" commensurate with their power (Organski cited in Johnson, 2003). This pattern emerges due to state's security dilemma in which they are perplexed in determining their positions in an uncertain geopolitical situation.

As one of region's rising powers, Indonesia is willing to maintain the stability of peace and security without disrupting the existing order. Within the region, the dynamic of political and economic changes at least present three main challenges namely; first, challenge is concerned with domestic political and economic in member states of regional organization such as Association of Southeast Asia Nations (ASEAN); second, challenge is to balance the depth of regional economic cooperation with similar cooperation in political-security areas, and third challenge is to strengthen the resolve and capacity to address nontraditional security issues that have become more salient within the region (Sukma, 2010). On the other hand, Indonesia also has interests at stake in the region given the salient rejections towards the "ninedash line" published by China. Not intended to change the status quo, Indonesia prefers to behave benignly by offering the maritime-based cooperation in Global Maritime Nexus so that all actors in the region may possess an equal sharing of opportunities over the disputed area. Nonetheless, according to Mak (2010) in Asia Pacific's maritime realm, there are three principal interests group; the first are the established maritime nations, the great users of ocean who see freedom of navigation throughout the world as essential for their well-being such as the United States, Japan, and Singapore. Second, they are maritime nations such as China, India, and South Korea; and third the coastal states comprising Malaysia, Indonesia, the Philippines, Vietnam, and Cambodia. Each of them has different view in dealing with maritime security while most of the reasons are for the sake of national interests at stake.

\section{SEA POWER}

Geoffrey Till coined an idea that sea power holds four historic attributes intimately connected with each other, and each also exhibits the same cooperative and conflictual tendencies characteristics of international relations as illustrated in the figure below (Till, 2004).

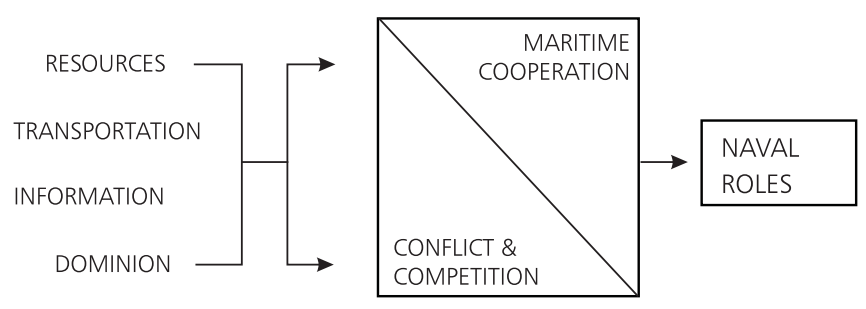

Figure 1. The Four Historic Attributes of Sea (Till, 2004)

Given the fact that sea possesses a huge amount of resources providing high road to prosperity, the need of making the most of it also increases. In order to get the enormous profits, it is important to make sure that a highly developed technology for transportation is applied. Furthermore, making sure its safety from such threats is another crucial point which needs that sort of sharing information with other actors playing within. However, dominion is seemingly inevitable since actors hold maritime strategies as Till further argued include assuring sea control, projecting power ashore in peace and war, attacking and defending trade, directly and indirectly, and maintaining good order at sea. Finally, naval roles will depend on the scale of either maritime cooperation or conflict and competition which potentially arise.

There have been numerous scholars coined the linkage between geographic and politics of the nation. Sir Halford John Mackinder who believed that world history was full of stories about conflict between land and sea powers highlighted that:

"New Europes were created in the vacant lands discovered in the midst of the waters, and what Britain and

Scandinavia were to Europe in the earlier time, that have America and Australia, and in some measure even TransSaharan Africa, now become to Euro-Asia." (Mackinder, 1904).

Furthermore, the analysis on the importance of sea power was gauged by Alfred Thayer Mahan, a United 
States admiral and geostrategic expert who perceived sea as a 'great highway' or 'wide common' which provides nations having access to it with a means of transport easier and cheaper than any which exists across land (Mahan cited in Bull, 1980). Military power through naval roles at sea is therefore seen as one of the fundamental elements in better supporting states' surveillance to safeguard national interests. He further argued that the way to achieve this goal was through the maintenance of great navy and superior fleet of capital ships able to crush the adversary. However, that sort of traditional sea power idea seems quite unattainable since nations are no longer in a Cold War period. There are now places for them to achieve goals or national interests such as bilateral cooperation, multilateral or regional discussion, and the United Nations legally established as the organization to safeguard peace and security in the world. If some states behave aggressively by stressing on great navy establishment, there will be many critiques from its neighbours based on universal international law where states should act accordingly. For all that, as the world rapidly changes, sea is no longer seen as the arena for military exercise but as an area full of strategic opportunities for every international actor. Cooperation is thus expected to halt any possibility of growing competition. Yet, it is important to note that states who agree upon such cooperation should also make a clearly legal limitation on territorial border in where they are entitled to benefit from.

The South China Sea as a semi-enclosed sea holding huge amount of resources becomes a flashpoint for any states that have interests at stake. This area offers other potential in regard to the attribute of sea such as transportation, information, and also dominion which might occur due to great power projections. However, in the long run, the full development of regional economic ties will depend on the evolution of the political relationship among the major Asian powers thereby if these relationships turn sour and suspicious, the movement toward wider and deeper economic integration will falter and could collapse (Friedberg, 1994). Dispute over borders and resources in the South China Sea remain the major chronicles for the steps toward a mutually integrated cooperation in the region. Evolving position of claimants exacerbate the dispute as each claimant rests on their own perspective on claiming the disputed zone. Some states seem to align into the U.S. while some others maintain a delicate pattern of partnership with China thereby Southeast Asia is more likely to be divided in regard to this dispute. Nonetheless, by having an agreed consensus on the basis or maritime cooperation as proposed by Indonesia through Global Maritime Nexus (GMN), the level of security dilemma is expected to decline since the states will therefore have a chance to benefit from the existing transportation and information opportunities through a formal forum thereby dominion may also be reduced.

Therefore, drawing upon the relationship between security dilemma and sea power, Indonesia's maritime vision will explore the roles which they play in pursuing national interests and maintaining neutrality in the South China Sea dispute. The notion of security dilemma has been useful in explaining Indonesia's awareness towards security and economic interests at stake amidst uncertainty in international affairs structured of overlapping interests between global power notably known as the U.S. and China. Security dilemma defines Indonesia's anxiousness to concern on their security from being dominated or annihilated by other states. Thus, it is formulated into Indonesia's focus on sea power as seen as in the newly established maritime vision, to offer a potential solution for peace in the South China Sea through cooperation which would take place in regional level. In Indonesia itself, maritime vision through GMN is seen as the new approach for international affairs despite its status as an archipelagic state. Literature about GMN is currently limited since this policy has just been implemented with an official blueprint which remains in progress. However, Indonesia's maritime vision will mostly aim at achieving economic benefit and political influence through which Indonesia could play a more significant and contributive role in shaping regional order. This will be applied through an analysis on 
different levels; maintaining neutrality which will therefore carry consequences to promote peace among the global power projections and pursuing national interests which requires strategic attempts. Finally, minimizing conflict and increasing the potential opportunities through regional based cooperations would be the prominent goals to achieve on this basis.

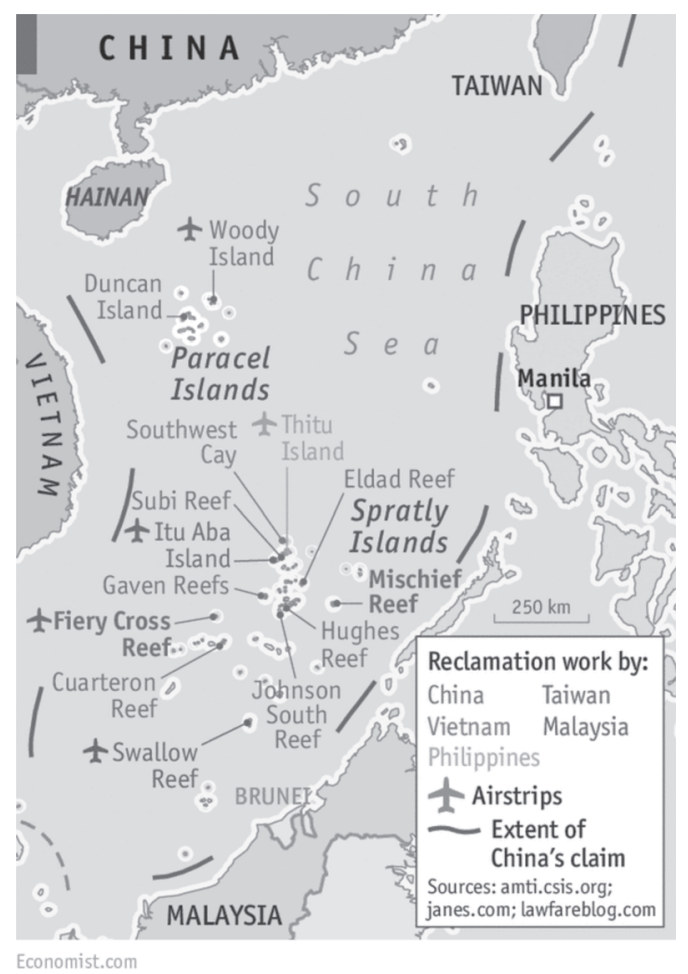

Figure 2. Map of disputed area in the South China Sea

Source:http://www.economist.com/news/leaders/21650122-disputed-sea-growing-securitynightmareand-increasingly-ecological-one-seatroubles? zid =306\&ah $=1 \mathrm{~b} 164 \mathrm{dbd} 43 \mathrm{~b} 0 \mathrm{cb} 27 \mathrm{ba0d} 4 \mathrm{c} 3 \mathrm{~b} 12 \mathrm{a} 5 \mathrm{e} 227$ GLOBAL POWER PROJECTIONS IN THE SOUTH CHINA SEA

The current disorder springs not from the wellknown issues of naval rivalry and military balance on the sea during World War, but from a revolution in the rules and norms by which states regulate their activity on the global commons of the oceans (Buzan, 1980). The Asia Pacific as one of the areas where states' interests overlap has huge potential of both opportunities and conflicts more specifically in the South China Sea where the contested primacy of major powers is contested. The notion of the U.S. Rebalance to Asia vis-à-vis China Peaceful Rise, which has been predominantly marked by mistrust, often leads states to face a security dilemma. It is therefore reflected in the defence strategy in order to ensure countries' interests from being threatened by others.

The picture above depicts the disputed area, which has increased states' security levels in the region. If the parties involved keep asserting their power leverage, through for instance China and its reclamation at Paracel Islands, I would predict the conceivable predicament surrounding the South China Seas could conceivably grow worse in the next couple of years. Despite the existing legal basis concerning the codification of the law of the sea in UNCLOS (United Nations on the Law of the Sea), the two regional powers; the United States and China, are seemingly 'muscle-flexing' by escalating assertiveness in territorial claims of the South China Sea. Buzan (1980) further argued that the growing turbulence of disagreement in the sea was due to these two factors; first, a dramatic rise in the realisable economic value of the oceans; and second, the rapid spread of sovereign states to cover virtually all the land areas of the planet triggered by the need of the ever-increasing population seeking high standards of living.

\section{US REBALANCE TO ASIA}

One of the most illuminating statements delivered by US Secretary of Defense Ash Carter on his remarks on the next phase of the U.S. Rebalance to the Asia Pacific was:

"Asia Pacific is the defining region for our nation's future given a few data points: half of humanity will live there by 2050, even sooner by 2030 more than half of the global middle class and its accompanying consumption will come from there, and it is already home to some of the world's largest militaries and defense spending." (Defense U. D., Secretary of Defense Speech, 2015).

After the U.S. war in Middle East, they are now thinking of focusing on their pivot point in Asia since it is considered as one of the key drivers of global politics. U.S. argued that they have underwritten regional security for decades patrolling Asia's sea lanes and preserving stability (Clinton, 2011). However, 


\begin{tabular}{lllll}
\hline & Unit & $2000 \mathrm{E}$ & $2010 \mathrm{E}$ & $2015 \mathrm{E}$ \\
\hline Energy Net Import & Mtce & $27.00-33.37$ & $124.04-146.41$ & $226.23-291.13$ \\
Coal & $\mathrm{Mt}$ & 2 & 4 & 5 \\
Oil & $\mathrm{Mt}$ & $35.00-40.00$ & $90.00-103.00$ & $125.00-145.00$ \\
Natural Gas & $\mathrm{Bm}$ & $1.2-2.0$ & $17.0-22.0$ & $60.00-90.0$ \\
\hline
\end{tabular}

Source: Author's projection based on China's statistical Yearbook2010 (Shixian, 2000)

NOTE: Coal net import is minus; it refers to net export

E: Estimate; $\mathrm{bm}^{3}$ : billion cubic meters, Mtce: million tons of coal equivalent; Mt: million tons.

China's rise has led the U.S. to think about the strategic implication which implies the increase of military presence of the U.S. has in the region. This condition of a security dilemma which occurs due to an uncertainty in international relations has worried the U.S. so that expanding military presence is critical to secure their interests at stake in the region. The U.S. engagement in the region is seen in their involvement in the establishment of the APEC Leaders' Meeting and other forms of cooperation such as ASEAN Regional Forum (ARF), ASEAN Plus Three, and East Asia Summit. This form of cooperation could be interpreted as insecurity dynamic reflection in U.S.' strategy by knowing other state's motives better so that they could engage in the worst-case scenario planning due to the rise of China. U.S. also needs to ensure their energy security as Kent Calder, an American scholar has argued that the "radical energy vulnerability" of key states in the region and the rise of China as both "an emerging superpower and an emerging competitor...for potentially tight regional energy supplies" compounds the potential for energy to become a "catalyst for regional conflict" (Calder cited in Stares, 2000). Therefore suggests the idea proposed by Till (2004) that the first part of historical attribute of the sea, how resources drive states to either engage in any sort of maritime cooperation or conflict and competition. The U.S. somehow plays a seemingly more balanced action by establishing cooperation despite the fact that this condition might trigger competition in the region due to the unbalance economic power between U.S. and other Asia Pacific regions mostly developing states.

\section{CHINA PEACEFUL RISE:}

China, despite its status as one of the regions' wealthiest countries still needs its dependence on imported sources of energy. Since 1993 it has been a net importer of oil and gas, while since 1996 it has become a net importer of crude oil. The major Asia Pacific sources were Indonesia $(6.30 \mathrm{Mt})$ and Vietnam $(1.01 \mathrm{Mt})$ and import will likely continue to grow in the future (Shixian, 2000). Table below illustrates the energy net import projections of China:

This situation, in turn, will contribute to and complicate the problem of the existing maritime boundary dispute in the South China Sea, as China's heavy dependence on the energy imports from Southeast Asian countries is facing U.S. who also asserts their rebalance in Asia, more specifically the importance of the future energy demands. It is worth noting that what is unfolding in Asia is a race between the accelerating dynamics of multipolarity, which could increase the chances of conflict, and the growth of mitigating factors which will improve potential continuing peace on the region (Friedberg, 19931994). The dynamic of security dilemma-driven actionreaction is seen in the economic and military competition which both US and China assert. Given the high tension of competition, both states need to make sure that their policy and actions over the South China Sea are in line with the principle of peace. Miscalculation would lead to the risk of unintended escalation in the future. Even though China keeps insisting that it will never enter into harsh conflict when it comes to any dispute, its behaviour through People Liberation Army (PLA) modernisation and other assertive re- 
sponses in the South China Sea showed that they hold a huge amount of interests at stake there. Fu Ying, a spokeswoman for the National People's Congress on March 3, 2015 stated that:

"As a large country, China needs the military strength to be able to protect its national security and people as our history teaches us a lesson that when we lag behind, we come under attack. We won't forget that. Furthermore, we need to continue modernising armed forces since there was still a gap between us and other countries in terms of military equipment" (The Wall Street Journal, 2015)

This strongly depicts a possibility of an arm races in the region, which may involve China and U.S. as the regions' most powerful actors. In regard to the South China dispute, China persistently displays an assertive behaviour seen by the latest reclamation of the Spratly Islands. This has raised U.S. concern by Republican Senator John McCain and Democrat Jack Reed who sent a letter to U.S. Secretary of State John Kerry and U.S. Defence Secretary Ash Carter stating that the U.S. should build a strategy that includes measures to "slow down or stop China's reclamation activities there, by either releasing intelligence about this activity more frequently or by stopping certain types of security cooperation with China if necessary (Brunnstrom, 2015). Indonesia, as one of the natural leaders in the region, tries to respond the heightened power competition between U.S. and China in these particular situations by enunciating maritime cooperation, which may lessen the possibility of great power projections in the region as states are more likely to cooperate instead of competing.

\section{THE SIGNIFICANCE OF MARITIME VISION TOWARDS MARITIME BOUNDARY DISPUTE IN THE SOUTH CHINA SEA}

\section{SECURITY DILEMMA IN THE SOUTH CHINA SEA}

In the post-Cold-War era, the South China Sea could possibly become one of the most explosive zones in the world with such complex overlapping sovereignty claims. There are four contested areas in the South China Sea, notably known as the Paracels claimed by China, Taiwan, and Vietnam; the Spratly Islands claimed by China, Taiwan, Vietnam, the Philippines, Malaysia, and Brunei; the Scarborough Shoal claimed by China, Taiwan, and the Philippines; and the Pratas Island and Macclesfield Bank claimed by China, Taiwan, the Philippines, and Vietnam. Given the highly escalated claims among states which could lead to dangerous competition, it is critical to seek a peaceful approach to dispute settlement. As explained previously, both China and the U.S. have interests at stakes in the South China Sea which consequently lead them to assert more power and influence in the region. Indonesia sees itself as a nonclaimant states despite the fact that one part of China's claim in its 'nine dashed line' overlaps with Indonesia's exclusive economic zone in Natuna Island. However, Indonesia prefers to promote a confidencebuilding measure as emphasized by Professor Hasjim Djalal, an expert of international law of the sea who is also a former Indonesian diplomat, by strengthening the importance of undertaking cooperation for emphasizing mutual benefits in areas where conflicting territorial claim exists, including exchanges of information and joint developments (Djalal, 2013).

With regard to the dispute, China has made series of compliments sent by the Permanent Mission of the People's Republic of China to the United Nations to the Secretary-General of the United Nations with reference to the Republic of Philippines Note Verbale no. 000228 on Spratly Island (in Tagalog: Kalayaan) which confirmed that:

"The so-called Kalayaan Island Group (KIG) claimed by the Republic of Philippines is in fact part of China's Nansha Island .... Since 1970s, the Republic of Philippines started to invade and occupy some islands and reefs of China's Nansha Islands and made relevant territorial claims, to which China objects strongly. The Republic of Philippines' occupation of some islands and reefs of China's Nansha Islands as well as other related acts constitutes infringement upon China's territorial sovereignty" (DOALOS, 2009).

At the ASEAN Regional Forum in Hanoi in July 